\title{
Close to the Heart or Close to the Home? Motivational Factors Influencing EFL Teaching as a Career Choice among Female Arab Citizens of Israel Students
}

\author{
Iman Garra-Alloush $^{1}$, Wisam Chaleila ${ }^{1} \&$ Abeer Watted $^{1}$ \\ ${ }^{1}$ Al-Qasemi Academy, Baqa Al-Garbiyeh, Israel \\ Correspondence: Iman Garra-Alloush, Al Qasemi Academy, Israel.
}

Received: November 10, 2020

Accepted: December 7, 2020

Online Published: December 17, 2020

doi: $10.5539 /$ elt.v14n1p48

URL: https://doi.org/10.5539/elt.v14n1p48

\begin{abstract}
The purpose of this study is to examine pre-service teachers' motivations for choosing English as a foreign language (EFL) teaching as a future profession for Female Arab citizens living in Israel. Data were gathered using the adapted Factors Influencing Teaching Choice (FIT-Choice) scale. Study participants (a cohort of $\mathrm{N}=100$ ) responded to a questionnaire of 38 motivational factors that had influenced them to choose English teaching as a future profession when entering education colleges. In addition, 20 of the participants took part in semi-structured interviews. Results revealed that the reasons Arab students become English teachers are based on a combination of intrinsic, extrinsic, and altruistic motivations. As all study participants were women, our results provide an initial indication of what draws Arab women living in Israel to the profession.
\end{abstract}

Keywords: teaching motivations, EFL teachers, Arab-Israelis, pre-service teachers, FIT-Choice scale, qualities of good teachers

\section{Introduction}

According to the Central Bureau of Statistics in Israel, the Arab population living in Israel is 1.85 million. Despite the fact that a large segment of the Arab population places great importance on the issue of education in Arab society, the 2018 Knesset report on Arab sector education revealed that there are thousands of unemployed Arab teachers who do not enter the teaching profession after graduating. Recent government reports show a massive surplus of teachers in the Israeli-Arab sector (Vinenger, 2018). According to Ministry of Education figures from 2016, approximately 12,000 Arab students graduate each year from education colleges, yet only $30 \%$ of them end up pursuing a career in the education system (Baruch, 2016). Still, many Arab high school graduates, particularly women, prefer to go into teaching as a future career.

While there is considerable literature on new teachers, teacher attrition, teacher retention, and teacher turnover in other developed countries (as documented in Henke et al., 2001; Buchanan et al., 2013), there is relatively little research on education as a career choice among the Arab minority living in Israel. In the Israeli context, teaching is generally regarded as a guarantee of job security, although it does not necessarily come with a concomitant socio-economic status (compare to Jeong, 2016).

Given the importance of teaching as a profession, it is crucial to ascertain why pre-service teachers opt for this career choice. Marshall (2009) pointed out that the act of choosing and completing an undergraduate teaching major seems to be related to teacher persistence. Identifying and understanding the motivations of pre-service teachers can help educators offer quality experiences to teaching candidates in their teacher preparation colleges and programs, ultimately producing competent and enthusiastic teachers (Cave \& Mulloy, 2010).

Our study is a first step toward addressing this research gap in the Israeli educational landscape, by looking at the reasons why pre-service English as a foreign language (EFL) teachers from the Arab minority choose teaching for their future careers. In service of this research goal, we sought to answer the following research questions:

1. What are the factors influencing Arab EFL pre-service teachers' career choice?

2. What types of factors are more dominant in Arab EFL pre-service teachers' career choice according to the FIT-Choice scale ranking? 


\section{Why do female Arab students choose to be teachers?}

\section{Literature Review}

Education is one of the most important pillars of a country's future and the building block of a brighter generation. While each country's individual culture will exert a certain degree of influence, teachers and educators around the world tend to enjoy a high socio-economic status (Manuel \& Hughes, 2006; Jeong, 2016). With this status comes significant job pressure, which may scare potential teachers from realizing their dream of pursuing a teaching degree. It also makes it difficult for policymakers to make teaching attractive to future candidates (Ramsay, 2000). As a result, numerous studies across the world have researched the motivations for becoming a teacher among both novice and pre-service teachers. Reports from the United States, the UK, Australia, and other European countries point to the difficulty of finding qualified teachers while they express concerns about teacher shortages (Liu et al., 2000; OECD, 2004; Preston, 2000).

When considering teacher training programs, it is crucial to identify the motivation for teaching since it can provide a valuable tool to guide newcomers considering teaching as a career choice. Many scholars have proposed different definitions for motivation. Among them, Schunk and others (2012) define it as "the process by which goal oriented activities are incorporated and sustained". Linder (1998) defines it as "the inner force that drives individuals to accomplish personal goals".

Richardson and Watt (2007) came up with the framework of FIT-Choice, defining it as "a scale that determines the strength of influence for a range of motivations from individuals choosing teaching as a career". They based their model on the expectancy-value framework, which is the most comprehensive motivational model for career choice (Wigfield \& Eccles, 2000). Watt and Richardson's study included 1,653 pre-service teachers from both graduate and undergraduate teaching programs across three different universities in Australia. They analyzed participants' demographic, career realization, occupational status on the scale 1-5 (5 being the highest), motivation for choosing teaching (extrinsic, intrinsic, and altruistic values), propositions about the profession, and finally career choice satisfaction.

A number of researchers have adapted the FIT-Choice scale since then, but only with minor modifications or adaptions to suit their intended audience. Jeong (2016) utilized the original model and adapted it for Korean EFL pre-service teachers. Her model was further improved by making the surveys network-based and online, for example via Google surveys. Manuel and Hughes (2006) also developed their study from this model, with the addition of open-ended questions.

These studies assigned motivations for choosing teaching as a career into three main categories: intrinsic, extrinsic, and altruistic. Intrinsically motivated people do actions for inner satisfaction without looking at the consequences and the outcomes. In other words, people with intrinsic motivations become teachers for reasons that are related to the job itself, such as enjoyment of teaching, enjoyment of being with children/young people, using their expert knowledge, and taking on the challenge of teaching a "difficult" subject (Joeng, 2016). On the other hand, being extrinsically motivated indicates that the individual is affected by social/socio-cultural factors. Individuals with extrinsic motivations put more emphasis on outcomes that are not related to teaching itself, for example vacations, income, or social status. They are usually influenced by social pressures from society, their families, former teachers, or even friends. These pressures also encompass personal factors, such as having a convenient schedule for family life and having children, as well as job benefits (Pop \& Turner, 2009; Joeng, 2016). As its name indicates, the category labeled altruistic motivations comprises people who go into teaching because they want to help others, in this case students or society. People in this category believe they can make a change in the education system for the good of society. Alongside these three main categories, all studies incorporated other motivational factors, such as last-resort career, demographics, and other cultural conflicts.

Across all studies, intrinsic values dominated the motivations for teaching; these were followed by altruistic values, with teaching as a "fallback" career in last place. Pre-service teachers seemed less concerned about extrinsic values such as salary and status. Accounting for $65 \%-75 \%$ of respondents, female teaching candidates far outnumbered male participants in the surveys, especially among early years and primary teachers. While most participants viewed teaching as a career with high demands and low returns, they showed a surprisingly high satisfaction rate with their choice of career (Richardson \& Watt, 2007).

According to an OECD report (2005), the most common motives for choosing teaching as a career in developed countries such as France, Australia, Canada, and the UK were working with children, fulfilling intellectual potential, or contributing to society. In contrast, research results from less developed countries in Africa revealed that extrinsic motives such as wages, job security, and career status were more essential than anything else. In other 
words, the motivational factors for choosing teaching as a future career vary according to the socio-cultural and socio-economic context of a specific society.

To our knowledge, little research on this issue has been conducted in the Israeli context, particularly in relation to the motivations of teachers from the Arab minority. Arabs long ruled the territory of Israel (Palestine), but soon after 1948, the Zionist movement began its struggle to claim the promised land, with the result that the Arab population has been reduced to a mere $20 \%$ of the population in contemporary times (Lavie et al., 2018).

According to Lavie and others (2018), "the population of the Arab minority is an 'indigenous' population that views itself as subject to the hegemony of a majority that, for the most part, is not indigenous". Arabs in Israel are challenged to deal with the fact that they are a minority in the land of their forefathers, but under the jurisdiction of Jewish immigrants. Over the years, relations between Arabs and Jews have grown understandably tense, with the Arab minority living in pure isolation.

After many years of turmoil, where one community annually celebrated a day of independence while the other was mourning the Nakba, the nation came to the realization that the notable cleavage between Arabs and Jews had to gradually disappear (Amara \& Mar'i, 2002). The Arab minority began to assimilate into Israeli culture, and their boundaries were extended. For the first time, after years of being bound to the role of housewives and in rare cases teachers, Arab women in Israel were finally given the freedom to work outside the home and pursue careers of their choosing.

Teacher attitudes in the Arab education system are the result of various socio-cultural factors alluded to above. Teachers try to instill interpersonal contact among their students, as well as fostering a sense of belonging and security in the school. In practice, however, they tend to work in restrictive, part-time employment conditions without the therapeutic or professional staff to assist them in addressing the diverse needs of students. Additionally, the centralized administration adopted by principals at many Arab schools is based on an authoritative and forceful management style that contradicts modern conceptions of moral and collaborative leadership. It is a distant leadership style influenced by cultural characteristics that tend to negate emotions and exclude teachers from school decision-making processes.

Further, the unilateral links between the school and parents, the conflicts between stakeholders in the Arab education system, and the distrust of teachers and Arab society in the Israeli education system impair many teachers' sense of belonging. In summary, Israeli-Arab teacher motivations and attitudes toward students are characterized by an educational landscape that lacks individual autonomy.

\section{Methodology}

\subsection{Research Participants}

Participants in this study were 100 Arab-Israeli students majoring in EFL education at an Islamic college located in Israel with a population of $95 \%$ female Muslim Arab students. They came from all 4-year groups, ranging from first year to fourth year. All EFL students received an email inviting them to take part in the study. Out of a total of 148 students invited, 100 agreed to participate.

\subsection{Research Methods and Tools}

The current study applied a mixed-method design in which quantitative and qualitative techniques were prioritized equally (Johnson \& Onwuegbuzie, 2004). The quantitative data were collected using an online survey based on the FIT-Choice scale, adapted from Richardson and Watt (2006; 2007). To maximize participation, the survey was offered in both online and pen and paper format. The FIT questionnaire was administered in order to examine students' motivations for choosing English language teaching as their future profession. The questionnaire includes 38 items on a Likert-type scale, going from 1 (not at all) to 7 (extremely) how important each given item was in the students' career decision. The items are grouped into five lower-order factors and two higher-order factors representing a wide range of career choice motivations. The five lower-order factors captured by this scale are as follows: ability; intrinsic career value; fallback career; prior teaching and learning experiences; and social influences. The two higher-order factors captured by this scale are personal utility value and social utility value. The personal utility value factor is comprised of three lower-order factors: job security; time for family; and job transferability. The social utility value factor is comprised of an additional four lower-order factors: to shape the future of children/adolescents; to enhance social equity; to make a social contribution; and to work with children/adolescents.

The qualitative data were collected via semi-structured interviews. Twenty freshman and sophomores were interviewed. The interviews were conducted face to face and fully transcribed. Each interview took about 45 minutes and was audiotaped and accompanied by a research diary. 


\section{Results}

\subsection{FIT-Choice Responses}

High reliability of the FIT-Choice scale was observed in the present study, with a Cronbach's alpha of 0.91 for the overall scale and scores ranging from 0.50 to 0.95 for the 12 factors utilized. Table 1 presents the FIT-Choice subscale alphas, number of items, and sample items.

Table 1. FIT-Choice Subscale Alphas, Number of Items, and Sample Items

\begin{tabular}{|c|c|c|c|c|}
\hline $\begin{array}{l}\text { Higher-order } \\
\text { factor }\end{array}$ & Factor & Cronbach's $\alpha$ & $\mathrm{N}$ of items & Sample item \\
\hline $\mathbf{N} / \mathbf{A}$ & Ability & 0.87 & 3 & I have good teaching skills \\
\hline $\mathbf{N} / \mathbf{A}$ & Intrinsic career value & 0.90 & 3 & I am interested in teaching \\
\hline N/A & Fallback career & 0.75 & 3 & I chose teaching as a last-resort career \\
\hline \multirow[t]{3}{*}{$\begin{array}{l}\text { Personal } \\
\text { utility value }\end{array}$} & Job security & 0.82 & 3 & $\begin{array}{l}\text { Teaching will offer a steady career } \\
\text { path }\end{array}$ \\
\hline & Time for family & 0.84 & 5 & $\begin{array}{l}\text { Teaching hours will fit with the } \\
\text { responsibilities of having a family }\end{array}$ \\
\hline & Job transferability & 0.50 & 3 & $\begin{array}{l}\text { A teaching job will allow me to choose } \\
\text { where I wish to live }\end{array}$ \\
\hline \multirow[t]{4}{*}{$\begin{array}{l}\text { Social } \\
\text { value }\end{array}$} & $\begin{array}{l}\text { Shape future of } \\
\text { children/adolescents }\end{array}$ & 0.94 & 3 & $\begin{array}{l}\text { Teaching will allow me to influence } \\
\text { the next generation }\end{array}$ \\
\hline & Enhance social equity & 0.84 & 3 & $\begin{array}{l}\text { Teaching will allow me to benefit the } \\
\text { socially disadvantaged }\end{array}$ \\
\hline & $\begin{array}{l}\text { Make social } \\
\text { contribution }\end{array}$ & 0.87 & 3 & $\begin{array}{l}\text { Teaching allows me to provide a } \\
\text { service to society }\end{array}$ \\
\hline & $\begin{array}{l}\text { Work with } \\
\text { children/adolescents }\end{array}$ & 0.95 & 3 & $\begin{array}{l}\text { I want a job that involves working with } \\
\text { children/adolescents }\end{array}$ \\
\hline $\mathbf{N} / \mathbf{A}$ & $\begin{array}{l}\text { Prior teaching and } \\
\text { learning experiences }\end{array}$ & 0.91 & 3 & $\begin{array}{l}\text { I have had good teachers as } \\
\text { role-models }\end{array}$ \\
\hline $\mathbf{N} / \mathbf{A}$ & Social influences & 0.64 & 3 & $\begin{array}{l}\text { People I've worked with think I should } \\
\text { become a teacher }\end{array}$ \\
\hline
\end{tabular}

In order to answer our second research question, which targeted the more dominant factors, a quantitative analysis was conducted. Results revealed that Arab EFL college students generally rated ability, job security, and time for family as highest in their reasons for choosing teaching, followed closely by the ability to shape future of children/adolescents and to make a social contribution. Of all 12 factors, EFL college Arab students rated fallback career and job transferability as the least influential in their decision to choose teaching. Table 2 presents descriptive statistics for the FIT-Choice subscales. 
Table 2. Descriptive Statistics for the FIT-Choice Subscales

\begin{tabular}{llllll}
\hline Scale & $\mathrm{N}$ & $\mathrm{Min}$ & $\mathrm{Max}$ & $\mathrm{M}$ & $\mathrm{SD}$ \\
\hline Ability & 100 & 1.00 & 7.00 & 5.42 & 1.47 \\
Intrinsic career value & 100 & 1.00 & 7.00 & 4.79 & 1.91 \\
Fallback career & 100 & 1.00 & 7.00 & 3.80 & 1.88 \\
Job security & 100 & 1.00 & 7.00 & 5.50 & 1.42 \\
Time for family & 100 & 2.00 & 7.00 & 5.41 & 1.35 \\
Job transferability & 100 & 1.00 & 7.00 & 3.97 & 1.43 \\
Shape future of children/adolescents & 100 & 1.00 & 7.00 & 5.07 & 1.893 \\
Enhance social equity & 100 & 1.00 & 7.00 & 4.53 & 1.713 \\
Make social contribution & 100 & 1.33 & 7.00 & 5.01 & 1.683 \\
Work with children/adolescents & 100 & 1.00 & 7.00 & 4.43 & 2.153 \\
Prior teaching and learning experiences & 100 & 1.00 & 7.00 & 4.79 & 1.823 \\
Social influences & 100 & 1.00 & 7.00 & 4.91 & 1.50 \\
\hline Personal utility value & 100 & 1.91 & 6.55 & 5.04 & 0.97 \\
Social utility value & 100 & 1.08 & 7.00 & 4.76 & 1.74 \\
\hline
\end{tabular}

\subsubsection{Subscale Analysis}

A second step was to conduct a deeper analysis for each subscale, as presented below.

Ability. The ability subscale, which contains the components of an intrinsic motivation, assesses respondents' self-appraisal of their own teaching skills (McLean et al., 2019). It consists of three items. The subscale mean was $(\mathrm{M}=5.42, \mathrm{SD}=1.47)$. Participants scored lowest on the item "Teaching is a career suited to my abilities" $(\mathrm{M}=5.25, \mathrm{SD}=1.74)$ and highest for the item "I have the qualities of a good teacher" $(\mathrm{M}=5.58, \mathrm{SD}=1.58) . \mathrm{A}$ closer look at the item-specific means suggests that there is not a great deal of variance in the means of the items, as noted in Table 3.

Table 3. Descriptive Statistics for the Ability Items

\begin{tabular}{lll}
\hline Item & $\mathrm{M}$ & $\mathrm{SD}$ \\
\hline I have the qualities of a good teacher & 5.58 & 1.58 \\
I have good teaching skills & 5.44 & 1.63 \\
Teaching is a career suited to my abilities & 5.25 & 1.74
\end{tabular}

Intrinsic Career Value. The intrinsic career value subscale assesses the extent to which the individual has a genuine, intrinsic interest in and desire to pursue teaching (McLean et al., 2019). It consists of three items. The subscale mean was $(\mathrm{M}=4.79, \mathrm{SD}=1.91)$. Participants scored lowest on "I've always wanted to be a teacher" $(\mathrm{M}=4.28, \mathrm{SD}=2.20)$ and highest for "I like teaching" $(\mathrm{M}=5.15, \mathrm{SD}=2.06)$. A closer look at the item-specific means suggests that there is a moderate deal of variance in the means of the items (Table 4).

Table 4. Descriptive Statistics for the Intrinsic Career Value Items

\begin{tabular}{lll}
\hline Item & $\mathrm{M}$ & $\mathrm{SD}$ \\
\hline I am interested in teaching & 4.60 & 2.00 \\
I've always wanted to be a teacher & 4.28 & 2.20 \\
I like teaching & 5.15 & 2.06 \\
\hline
\end{tabular}

Fallback Career. The fallback career subscale assesses the extent to which respondents' view teaching as a "backup" or "second-choice" career (McLean et al., 2019). It consists of three items. The subscale mean was $(\mathrm{M}=3.80, \mathrm{SD}=1.88)$. Participants scored lowest on "I was not accepted into my first-choice career" $(\mathrm{M}=3.35$, $\mathrm{SD}=2.46)$ and highest for "I was unsure of what career I wanted" $(\mathrm{M}=4.21, \mathrm{SD}=2.25)$. A closer look at the item-specific means suggests that there is a great deal of variance in the means of the items (Table 5). 
Table 5. Descriptive Statistics for the Fallback Career Items

\begin{tabular}{lll}
\hline Item & $\mathrm{M}$ & $\mathrm{SD}$ \\
\hline I was unsure of what career I wanted & 4.21 & 2.25 \\
I was not accepted into my first-choice career & 3.35 & 2.46 \\
I chose teaching as a last-resort career & 3.86 & 2.19
\end{tabular}

Personal Utility Value. The personal utility value subscale assesses the individual's perceptions of the practical aspects of teaching as convenient to their desired lifestyle (McLean et al., 2019). It is comprised of three lower-order factors: job security (3 items); time for family (5 items); and job transferability ( 3 items). The overall mean for this subscale was $(\mathrm{M}=5.04, \mathrm{SD}=0.97)$. Participants scored lowest on job transferability $(\mathrm{M}=3.97, \mathrm{SD}=1.43)$, especially on the item "A teaching job will allow me to choose where I wish to live" $(\mathrm{M}=3.15, \mathrm{SD}=2.14)$; and highest for "School holidays will fit in with family commitments" $(\mathrm{M}=5.88$, $\mathrm{SD}=1.51)$. A closer look at the item-specific means suggests that there is a great deal of variance in the means of the items (Table 6).

Table 6. Descriptive Statistics for the Personal Utility Value Items

\begin{tabular}{llll}
\hline Subscales & Item & M & SD \\
\hline Job security & Teaching will offer a steady career path & 5.65 & 1.67 \\
& Teaching will provide a reliable income & 5.21 & 1.58 \\
& Teaching will be a secure job & 5.63 & 1.71 \\
Time for family & Part-time teaching could allow more family time & 5.25 & 1.91 \\
& Teaching hours will fit with the responsibilities of having a family & 5.72 & 1.66 \\
& School holidays will fit in with family commitments & 5.88 & 1.51 \\
& As a teacher I will have lengthy holidays & 5.32 & 1.66 \\
& As a teacher I will have a short working day & 4.90 & 1.83 \\
Job transferability & Teaching may give me the chance to work abroad & 3.59 & 2.22 \\
& A teaching qualification is recognized everywhere & 5.16 & 1.76
\end{tabular}

Social Utility Value. The social utility value subscale assesses the extent to which the respondent values making a positive contribution to society through working with children (McLean et al., 2019). It is comprised of four lower-order factors: to shape future of children/adolescents ( 3 items); to enhance social equity (3 items); to make a social contribution (3 items); and to work with children/adolescents (3 items). The overall mean for this subscale was $(\mathrm{M}=4.76, \mathrm{SD}=1.74)$. Participants scored lowest on work with children/adolescents $(\mathrm{M}=4.43$, $\mathrm{SD}=2.15)$, enhancing social equity $(\mathrm{M}=4.53, \mathrm{SD}=1.71)$, and especially assist the socially disadvantaged" $(\mathrm{M}=4.34, \mathrm{SD}=1.88)$. Scores for the item "Teaching allows me to provide a service to society" were highest $(\mathrm{M}=5.35, \mathrm{SD}=1.87)$. A closer look at the item-specific means suggests that there is a great deal of variance in the means of the items (Table 7).

Table 7. Descriptive Statistics for the Social Utility Value Items

\begin{tabular}{|c|c|c|c|}
\hline Subscales & Item & M & SD \\
\hline \multirow{3}{*}{$\begin{array}{l}\text { Shape future of } \\
\text { children/adolescents }\end{array}$} & Teaching will allow me to shape child/adolescent values & 4.97 & 2.05 \\
\hline & Teaching will allow me to influence the next generation & 5.23 & 2.02 \\
\hline & Teaching will allow me to have an impact on children/adolescents & 5.00 & 1.94 \\
\hline \multirow[t]{3}{*}{ Enhance social equity } & Teaching will allow me to raise the ambitions of underprivileged youth & 4.85 & 1.95 \\
\hline & Teaching will allow me to assist or aid the socially disadvantaged & 4.34 & 1.88 \\
\hline & Teaching will allow me to work against social disadvantage & 4.40 & 2.08 \\
\hline \multirow[t]{3}{*}{ Make social contribution } & Teaching allows me to provide a service to society & 5.35 & 1.87 \\
\hline & Teachers make a worthwhile social contribution & 4.86 & 1.82 \\
\hline & Teaching enables me to "give back" to society & 4.83 & 2.00 \\
\hline \multirow{3}{*}{$\begin{array}{l}\text { Work with } \\
\text { children/adolescents }\end{array}$} & I want a job that involves working with children/adolescents & 4.35 & 2.31 \\
\hline & I want to work in a child/adolescent-centered environment & 4.35 & 2.19 \\
\hline & I like working with children/adolescents & 4.59 & 2.24 \\
\hline
\end{tabular}


Prior Teaching and Learning Experiences. The prior teaching and learning experiences subscale assesses the extent to which students were inspired by previous teachers or by their own experiences teaching students (McLean et al., 2019). It consists of three items. The subscale mean was $(\mathrm{M}=4.79, \mathrm{SD}=1.82)$. Participants scored all items similarly (Table 8).

Table 8. Descriptive Statistics for the Prior Teaching and Learning Experiences Items

\begin{tabular}{lll}
\hline Item & $\mathrm{M}$ & $\mathrm{SD}$ \\
\hline I have had inspirational teachers & 4.82 & 1.97 \\
I have had good teachers as role-models & 4.78 & 1.96 \\
I have had positive learning experiences & 4.78 & 1.98 \\
\hline
\end{tabular}

Social Influences. The social influences subscale assesses the extent to which others (family and/or friends) encouraged or expected them to become a teacher (McLean et al., 2019). It consists of three items. The subscale mean was $(\mathrm{M}=4.91, \mathrm{SD}=1.50)$. Participants scored lowest on "My friends think I should become a teacher" $(\mathrm{M}=4.04, \mathrm{SD}=2.25)$; and highest for "My family thinks I should become a teacher" $(\mathrm{M}=5.79, \mathrm{SD}=1.67) . \mathrm{A}$ closer look at the item-specific means suggests that there is a great deal of variance in the means of the items (Table 9).

Table 9. Descriptive Statistics for the Social Influences Items

\begin{tabular}{lll}
\hline Item & M & SD \\
\hline My friends think I should become a teacher & 4.04 & 2.25 \\
My family think I should become a teacher & 5.79 & 1.67 \\
People I've worked with think I should become a teacher & 4.89 & 1.94 \\
\hline
\end{tabular}

\subsubsection{Dominant Motivation}

Across the 38 questionnaire items $(38 \times 100=3800$ answers $)$, respondents rated the intrinsic and extrinsic motivations higher than the altruistic reasons. The items with the highest score turned out to be intrinsic, with "I am interested in teaching [English]", "I have always wanted to be a [n English] teacher", and "I like teaching [English]" receiving ratings of 6 or 7 on the Likert scale. In all, $88 \%$ of the pre-service teachers selected intrinsic motivations. Among the 14 items indicated as extrinsic, participants pointed to $82 \%$ of the answers as extrinsic, specifically the items "Part-time teaching could allow more family time", "Teaching hours will fit with the responsibilities of having a family", and "School holidays will fit in with family commitments". Participants also attributed the item "I was not accepted into my first-choice career") with a rating of 5-7 on the Likert scale. "I chose teaching as a last-resort career" received a relatively high rating (5-6) on the Likert scale.

Items belonging to the altruistic category were given lower ratings (1-4 on the Likert scale). For example, "Teaching enables me to 'give back' to society" was given a 3 by $85 \%$ of the participants.

\subsection{Semi-Structured Interviews}

Aside from the questionnaire, the following questions were asked in the qualitative interviews:

Why did you choose to study English?

Why did you choose to study at Al-Qasemi Academy?

Why do you want to be a teacher?

The following themes appeared in the coding of the semi-structured interviews:

Studying at a college that is close to home: One of the most prominent themes, mentioned in 15 out of 20 interviews, is the fact that the college they chose is close to their homes. All 20 interviewees said they think they will eventually get a job close to their homes. Further, all respondents believe that there is a shortage of English teachers in Arab society (although this view is based on popular belief rather than scientific evidence). One of the interviewees named Maram (all names mentioned are pseudonym) said: "Al-Qasemi is the closest college to my home. It would be more convenient for my family life in the future to study in a place that is close to my house." Muna, an engaged student, expressed a similar sentiment when she said: "I'm getting married next year. I suppose that studying in a place close to my home would be most convenient for my family life, especially after getting married." Ahlam alluded to religious reasons to explain her choice of college: "I come from a conservative religious family. I am also a conservative girl. I cannot study in a faraway place because I have to be accompanied by mahram. This is a key reason for coming to study at Al-Qasemi college because it is close to 
my house." Mahram is a well-known term in the Islamic context, indicating a close member of a woman's family-usually a husband, father, grandfather, brother, or uncle-who may serve as a legal escort or chaperon for journeys longer than a day and a night. Alham's explanation was also repeated in Suha's and Ibtihal's answers.

English is the most prestigious job among all teaching professions: For a majority of students (14 out of 20), the most common reason for choosing to teach English specifically was that "English teaching is the most prestigious among all teaching professions". One student, Ahmad, observed, "If I'm to become a teacher anyway, then I want to be an English teacher; it is the best of the worst!" (meaning the best among all teaching professions, but the worst because teaching is the worst job).

I think/ My family thinks that teaching is the best job for a woman in the future: All respondents (100\%) reported that they chose to be English teachers because it is the best profession for a woman who is going to be a mother in the future.

I love the English language: Apparent in both the questionnaire and the semi-structured interviews are the undergraduates' strong attachment to English as a subject. All respondents agreed that they loved the English language and enjoyed speaking English. They indicated that this passion for the language was an important factor in their decision to become English teachers.

\section{Discussion}

This study investigated the motivational factors behind Arab citizens of Israel female undergraduates' decision to train as English teachers. The research instrument was based on the FIT-Choice model. Data was collected through a questionnaire made available online and in hardcopy. Our respondents' future career choice was primarily driven by intrinsic motivational factors, underpinned by a strong interest in teaching and a love of the English language. Extrinsic factors, such as compatibility with motherhood and the relatively comfortable lifestyle that comes with being an EFL teacher, were also important. Altruistic motivations, however, were given the lowest ratings on the Likert scale. The questionnaire's findings were further supported by the themes that emerged in the semi-structured interviews.

Some of our findings appear to challenge prior work suggesting that teachers in more developed countries are attracted to altruistic motivations. However, the situation in Israel-inarguably a highly developed country-is not simple, and this complexity is reflected in our results. On the one hand, our participants were driven by intrinsic motivations, in line with other highly developed countries. On the other hand, few indicated altruistic motivations. Most respondents pointed to extrinsic motivations, such as teaching being a last-resort choice, or a "default career". Regional perceptions of teaching could provide a potential explanation for these motivational differences. In developed countries where teachers are driven by altruistic motivations, teaching tends to be perceived as a calling (e.g., Jeong, 2016), whereas in Israel, the position of teaching and teachers is considered to be low (Wongruvitch, 2018). Arabs living in Israel have the complex identity of living in a developed country, but they still have intrinsic motivations. This is due to the fact they are a relatively under-developed community, as they have a relatively low economic level and standard of living, within the borders of a developed country. On the other hand, being a teacher in a country like Israel is still regarded as a less prestigious job, which explains why it is usually chosen as a last resort choice.

\subsection{Conclusions and Recommendations}

Our study, and any future research developed from it, could be used to inform college teacher training programs in the Arab sector in Israel, helping course developers adapt their content to deliver quality and relevant experiences for future teachers. On the basis of our findings, it is possible to make some recommendations that could be implemented by policy makers in Israel in order to promote teaching as a calling. For example, teachers should receive higher salaries, and students with high grades in entrance exams should be accepted to education colleges. The fact that Arab-Israeli pre-service teachers ranked intrinsic factors as their chief motivation can be interpreted as positive evidence, since intrinsic motives have been linked to dedication to the profession (Jeong, 2016). That said, it could be argued that altruism also has an important role to play in teacher dedication. For this reason, the fact that altruistic motivations scored lowest in the ranking could reflect negatively on those who enter EFL teaching in the Arab sector in Israel. If altruistic motivations were to be strengthened, teachers' dedication to their jobs would potentially increase. This study has laid the foundations for future research into the motivations of teachers within the Arab education sector in Israel.

Future research should relate to the findings of the current study connect them to teachers' attrition as well as teachers' efficacy. In addition, the researchers think that there may be latent ties between the different motivations. A future study should focus on these correlations. These were not computed in this study due to the small sample. 


\section{References}

Al-Yaseen, W. S. (2011). Factors influencing Kuwaiti student teachers' choice of teaching as a profession. College Student Journal, 45(3), 667-680. https://mail.google.com/mail/u/0/\#search/shereen+/QgrcJHsBqzbbdglrqKMsmJFZbXPQPDFkRtV?project or $=1 \&$ messagePartId $=0.1$

Amara, M. (2002). Mar'I A. Language education policy: The Arab Minority in Israel, 41. https://doi.org/10.1007/0-306-47588-X

Artino, A., \& Ioannou, A. (2008). Promoting Academic Motivation and Self-Regulation: Practical Guidelines for Online Instructors. In K. McFerrin, R. Weber, R. Carlsen, \& D. Willis (Eds.), Proceedings of SITE 2008--Society for Information Technology \& Teacher Education International Conference (pp. 208-212). Association for the Advancement of Computing in Education (AACE). Retrieved from https:/www.learntechlib.org/primary/p/27160/

Baruch, Hazaki. (2016). Arab Teachers Are not Finding Work (Hebrew Article). Channel 7. Retrieved from https://www.inn.co.il/news/314481

Buchanan, J., Prescott, A., Schuck, S., Aubusson, P., Burke, P., \& Louviere, J. (2013). Teacher retention and attrition: Views of early career teachers. Australian journal of teacher education, 38(3). https://doi.org/10.14221/ajte.2013v38n3.9

Cave, A., \& Mulloy, M. (2010). How do cognitive and motivational factors influence teachers' degree of program implementation? A qualitative examination of teacher perspectives. National Forum of Educational Administration and Supervision Journal, 27(4), 1-26.

Hadad, N., \& Rodintzki, E. (2018, December 25). The Arab education system: A current picture and challenges of the future. The Israel Democracy Institute. Retrieved from https://www.idi.org.il/articles/25462

Henke, R., Zahn, L., \& Carroll, D. (2001). Attrition of new teachers among recent college graduates.

Jeong, K. O. (2016, February). A Study on Korean EFL Pre-Service Teachers' Motivations in Choosing Teaching as a Career. In 2016 International Conference on Platform Technology and Service (PlatCon) (pp. $1-4)$. IEEE.

Johnson, R. B., \& Onwuegbuzie, A. J. (2004). Mixed methods research: A research paradigm whose time has come. Educational researcher, 33(7), 14-26. Retrieved from https://mail.google.com/mail/u/0/\#search/korean/KtbxLrjGPfHrWcNfmzpKGjfRLHcQwmDDVV?projecto $\mathrm{r}=1$

Kim, E. (2006). Choosing Mathematics teaching as a career: An analysis of prospective teachers' reasons to become teachers. The Journal of Korean Education, 33(2), 51-73.

Kyriacou, B., \& Coulthard, M. (2000). Undergraduates' views of teaching as a career choice. Journal of Education for Teaching, 26(2), 117-126. https://doi.org/10.1080/02607470050127036

Lavie, E. (2018). Integrating the Arab-Palestinian minority in Israeli society: Time for a strategic change. Institute for National Security Studies.

Lindner, J. R. (1998). Understanding employee motivation. Journal of extension, 36(3), 1-8.

Manuel, J., \& Hughes, J. (2006). It has always been my dream: Exploring pre-service teachers' motivations for choosing to teach. Teacher Development, 10(1), 5-24. https://doi.org/10.1080/13664530600587311

Marshall, J. M. (2009). Describing the elephant: Preservice teachers talk about spiritual reasons for becoming a teacher. Teacher Education Quarterly, 36(2), 25-44. Retrieved from https:/www.jstor.org/stable/23479250

McLean, L., Taylor, M., \& Jimenez, M. (2019). Career choice motivations in teacher training as predictors of burnout and career optimism in the first year of teaching. Teaching and Teacher Education, 85, 204-214. https://doi.org/10.1016/j.tate.2019.06.020

OECD. (2004). Attracting, developing and retaining effective teachers. Retrieved from https://www.oecd.org/document/9/0,2340,en_2649_34521_11969545_1_1_1_1,00.html

Pop, M., \& Turner, J. E. (2009). To be or not to be a teacher? Exploring levels of commitment related to perception of teaching among students enrolled in a teacher education program. Teachers and Teaching: Theory and Practice, 1(6), 683-700. https://doi.org/10.1080/13540600903357017 
Preston, B. (2000). Teacher supply and demand to 2005: projections and context. Canberra: Australian Council of Deans.

Ramsey, G. A. (2000). Quality Matters: Revitalising Teaching: Critical Times, Critical Choices: Executive Summary: Report of the Review of Teacher Education. NSW Department of Education and Training.

Sali, P. (2013). Understanding motivations to become teachers of English: ELT trainees' perceptions. Social and Behavioral Sciences, 93, 1418-1422. https://doi.org/10.1016/j.sbspro.2013.10.055

Schunk, D. H., Meece, J. R., \& Pintrich, P. R. (2012). Motivation in education: Theory, research, and applications. Pearson Higher Ed.

Snyder, J. F., Doerr, A. S., \& Pastor, M. A. (1995). Perceptions of preservice teachers: The job market, why teaching, and alternatives to teaching. Slippery Rock University.

Thomson, M. M., \& Palermo, C. (2014). Preservice teachers' understanding of their professional goals: Case studies from three different typologies. Teaching and Teacher Education, 44, 56-68. https://doi.org/10.1016/j.tate.2014.08.002

Thomson, M. M., Turner, J. E., \& Nietfeld, J. L. (2012). A typological approach to investigate the teaching career decision: motivations and beliefs about teaching of prospective teacher candidates. Teaching and Teacher Education, 27, 579-588. https://doi.org/10.1016/j.tate.2011.10.007

Vinenger, Asaf. (2018). A look at the Arab Education (in Hebrew). Knesset Department of Research and Science. Education. Retrieved from https://fs.knesset.gov.il/globaldocs/MMM/e55d7b99-5f6e-e811-80e2-00155d0a9876/2_e55d7b99-5f6e-e81 1-80e2-00155d0a9876_11_10642.pdf

Watt, H. M. G., \& Richardson, P. W. (2007). Motivational factors influencing teaching as a career choice: Development and validation of the FIT-Choice Scale. Journal of Experimental Education, 75(3), 167-202. https://doi.org/10.3200/JEXE.75.3.167-202

Watt, H. M. G., \& Richardson, P. W. (2012). An introduction to teaching motivations in different countries: Comparisons using the FIT-Choice scale. Asia-Pacific Journal of Teacher Education, 40(3), 185-197. https://doi.org/10.1080/1359866X.2012.700049

Watt, H. M. G., Richardson, P. W., Klusmann, U., Kunter, M., Beyer, B., Trautwein, U., \& Baumert, J. (2012). Motivations for choosing teaching as a career: An international comparison using the FIT-Choice scale. Teaching and Teacher Education, 28(6), 791-805. https://doi.org/10.1016/j.tate.2012.03.003

Wigfield, A., \& Eccles, J. S. (2000). Expectancy-value theory of achievement motivation. Contemporary educational psychology, 25(1), 68-81. https://doi.org/10.1006/ceps.1999.1015

Wong, A., Tang, S., \& Cheng, M. (2014). Teaching motivations in Hong Kong: Who will choose teaching as a fallback career in a stringent job market? Teaching and Teacher Education, 41, 81-91. https://doi.org/10.1016/j.tate.2014.03.009

Wongruvitch, N., \& Yitzhak, G. (2018). Teachers' Position in the Israeli Society Today (Hebrew). Dapim, 68, 11-27. Retrieved from https://library.macam.ac.il/study/pdf_files/d12899.pdf

\section{Copyrights}

Copyright for this article is retained by the author(s), with first publication rights granted to the journal.

This is an open-access article distributed under the terms and conditions of the Creative Commons Attribution license (http://creativecommons.org/licenses/by/4.0/). 